\title{
直流サーボモータの摩擦トルク†
}

\author{
服 部 正 行・高 梨 良一・安 濃 恒 友 \\ 山形大学工学部 米沢市城南 4-3-16
}

(昭和 44 年 9 月 1 日 受付)

\section{On the Friction-Torque of DC Servomotor}

Masayuki Hattori, Ryoichi Takanashi and Tsunetomo Anno

(Faculty of Engineering, Yamagata University, Yonezawa)

(Received September 1, 1969)

Friction-torque characteristics of DC servomotor in the range of lower speed have not been measured because the motor, in this range, could not even sustain rotation, not to speak of rotating with constant speed.

In this report, measuring method of such characteristics using rate feedback and experimental results on conventional motors are described.

Furthermore it is clarified that the friction-torque of the DC motor in the range of lower speed are concerned with not only motor speed but also angular position of rotor of the motor.

\section{1. ま え がき}

直流サーボモータは, 簡単には線形の 1 次遅れ要素 として取り扱われるが，実際にはその特性の中に種々 の非線形性が観測されるので非線形素子として取り扱 われることも多い，特に速度対摩擦特性に表われる非 線形性は顕著であり，位置制御系に和汀る定常偏差の 原因や，小さな変化速度を有する入力信号に対してジ ャーキングモーションを発生させる原因となるために, 従来からしばしば取り上げられてきている，その代表 的な考方方は，モータの静止中は静止摩擦を考元，モ 一タの回転中の摩擦はクーロン摩擦と速度に比例する 粘性摩擦の和であるとする考方方である.

しかしながら実際には，一般の直流サーボモータで は，その定格や構造によって程度の差はあるが，回転 角速度の小さいところでは，モータを一定速度で回転 させることはもちろん，回転を持続させることさえる 不可能になる. その結果, 低速回転時に打ける摩擦卜 ルク特性を実験的に測定することができず，その部分 については種々の推測が行なわれているにすぎない．

たと亲ば，この測定ができない区間では，モータの 起動時と停止時とでそれぞれ異なった摩擦特性を持つ

†第 20 回計測自動制御学会東北支部研究会で一部 発 表 (昭 $43 \cdot 5$ )
と推定し，その特性を外そうしているもの吕や，位置 制御サーボ機構に怙けるジャーキ.ングモーションの発 生限界を求めるさいに, 回転角速度の小さい部分の摩 擦トルク特性に近似式を仮定して数值計算を行なって いるもの2)などをあげることができる。

このように，いずれの場合も低速回転に打ける摩擦 特性を推定するにとどまって郝り，この区間の測定を 行ならには低速でもモータの回転が持続するような方 法を考える必要がある。

モータの回転の状態を観察してみると, 回転角速度 を徐々に下げて行き，回転が持続できなくなる直前で は, 回転角速度に大きな变動を生じることが認められ る.この変動は, 摩擦トルクが変動することによって 生じるものと考㝋られるので，それを打ち消すような 方法をとれば, さらに小さい回転角速度に至るまで回 転を持続させることが可能になるものと考兄られる。 この摩擦トルクの変動を, 等価的にはモータの出力軸 に付加された外乱々考光るならば，モータに十分大き な速度帰還をかけることにより，その影響を軽減する ことが可能となる.

このような考光方に基づいて, モータ単体では回転 不能となる低速の状態での摩擦トルクを測定し ${ }^{3)}$, こ の区間の摩擦特性について検討を行なった4). その結 果, そのような低速の区間では, 摩擦は回転角速度の 
関数としてだげではなく，角位置にも関係しているこ とが明らかとなった。

\section{2. 摩摩トルクの測定}

\section{$2 \cdot 1$ 速度帰還がある場合のモータの関係式}

直流他励サーボモータを電機子制御で使用する場合 近似的に次の 2 式が成立する.

$$
\begin{aligned}
v_{a} & =R_{a} i_{a}+K_{b} \omega \\
K_{t} i_{a} & =J_{m} \frac{d \omega}{d t}+f
\end{aligned}
$$

ここで, $v_{a}$ : 電機子電圧 $\quad R_{a}:$ 電機子抵抗

$i_{a}:$ 電機子電流 $\quad K_{b}:$ 逆起電力定数

$\omega:$ 回転角速度 $K_{t}:$ トルク定数

$J_{m}:$ 電機子慣性モーメント

$f:$ 摩擦トルク

このモータに, Fig. 1 に示すような速度帰還をか けると次式が成立する。

$$
\begin{aligned}
v_{i} & =R_{a} i_{a}+\left(K_{b}+K_{\beta}\right) \omega \\
& =R_{a} i_{a}+\left(1+\frac{K_{\beta}}{K_{b}}\right) K_{b} \omega \\
& =R_{a} i_{a}+\Gamma K_{b} \omega
\end{aligned}
$$

ここで, $v_{i}$ : 入力電圧, $K_{e}$ : 速度帰還俰数

$$
\Gamma=1+K_{\beta} / K_{b}
$$

(4) 式で $\Gamma=1\left(K_{\beta}=0\right)$ となるのは速度 帰還をかけない場合に相当する。

\section{$2 \cdot 2$ 実験 方法}

モータの回転速度を一定とみなすことが できる場合は, (2) 式で $J_{m} \frac{d \omega}{d t}=0$, す なわち， $f \fallingdotseq K_{t} i_{a}$ となるので，モータの電 機子電流を測定し，これに $K_{t}$ を乗じて摩 擦トルクとする.

いっ涪う，モータの回転速度が時間的汇 変動する場合には, (2)式で $J_{m} \frac{d \omega}{d t}$ の項 の影響を考慮しなければならない。この場 合には Fig. 2 により， $f, \omega$ 抢よび回転角 変位： $\theta$ を測定する。

\section{3. 実 験 結 果}

実験使用したサーボモータは, 一般に 市販されている小形サーボモータのらち, 次の 2 種である.すなわち, T社製, 出力 $8 \mathrm{~W}$, 電機子電圧 $26.5 \mathrm{~V}$, 無負荷回転数 $15000 \mathrm{rpm}$ のもの（以下これをNo. 1 モ 一タといら）拈よび $\mathrm{S}$ 社製, 出力 $10 \mathrm{~W}$, 電機子電圧 $100 \mathrm{~V}$, 回転数 $3500 \mathrm{rpm}$ の るの（以下これを No. 2 モータという）

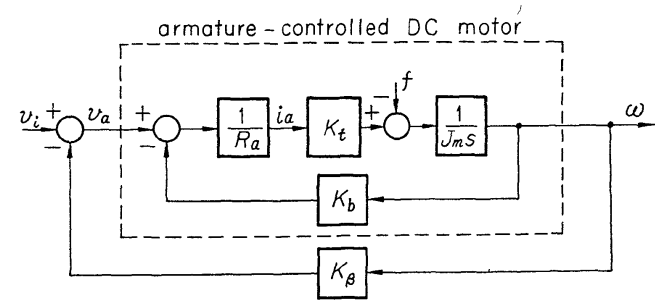

Fig. 1 Block diagram of the armature-controled DC motor with rate feedback,

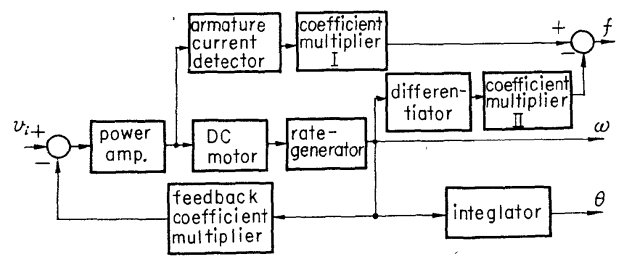

Fig. 2 General arrangemẹt for recording $f, \omega$ and $\theta$
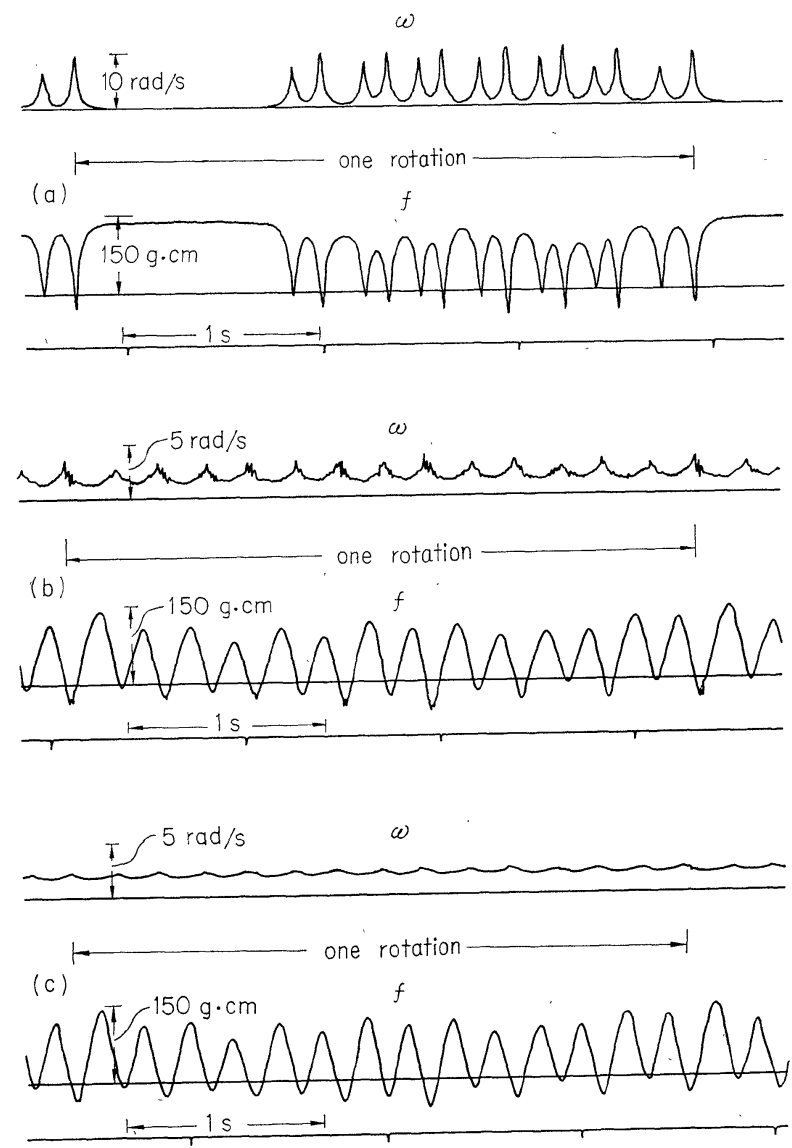

(a) $\Gamma=50, \quad \bar{\omega} \fallingdotseq 2[\mathrm{rad} / \mathrm{s}], \quad$ (b ) $\Gamma=500, \bar{\omega} \fallingdotseq 2[\mathrm{rad} / \mathrm{s}]$,

(c) $\Gamma=2000, \bar{\omega} \fallingdotseq 2[\mathrm{rad} / \mathrm{s}]$

Fig. 3 Records of $\omega$ and $f$ of No. 1 motor for several values of $\Gamma$ 
である。

No. 1 モータについて，たとえば $\Gamma=50$, 500 抢よび 2000 の場合に, 平均回転角速 度 $: \bar{\omega} \fallingdotseq 2 \mathrm{rad} / \mathrm{s}$ となるときの測定記録を 示せば Fig. 3 のよらになる. また， $\Gamma=$ 100 で $\bar{\omega} \fallingdotseq 1 \mathrm{rad} / \mathrm{s}, 2 \mathrm{rad} / \mathrm{s}$ 和よび $4 \mathrm{rad} / \mathrm{s}$ の測定記録を示せば Fig. 4 のようになる.

同様に, No. 2 モータについて $\Gamma=10$ および 50 の場合に $\bar{\omega} \fallingdotseq 1 \mathrm{rad} / \mathrm{s}$ となると きの測定記録は Fig. 5 のようになる.

ここで, 回転角速度の平均値と特に表示 したのは，モータの回転角速度が小さい場 合，その值が時間的に変動するので，その 時間平均をとり, 従来からの速度対摩擦特 性と関連づけて取り扱うことができるよう にするためである.

Fig. 3 によれば，モータの 1 回転に要 $\omega$


(a) $\Gamma=100, \bar{\omega} \fallingdotseq 1[\mathrm{rad} / \mathrm{s}]$, (b) $\Gamma=100, \bar{\omega} \fallingdotseq 2[\mathrm{rad} / \mathrm{s}]$

(c) $\Gamma=100, \bar{\omega} \fallingdotseq 4[\mathrm{rad} / \mathrm{s}]$

Fig. 4 Records of $\omega$ and $f$ of No. 1 motor for several values of $\bar{\omega}$

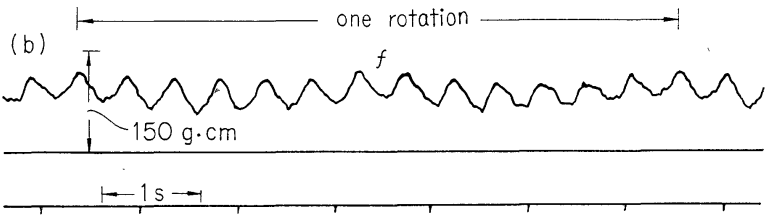

(a) $\Gamma=10, \bar{\omega} \fallingdotseq 1[\mathrm{rad} / \mathrm{s}]$,

(b) $\Gamma=50, \bar{\omega} \fallingdotseq 1[\mathrm{rad} / \mathrm{s}]$

Fig. 5 Records of $\omega$ and $f$ of No. 2 motor

する時間が同じでも，「の大小によって回 転の状態がいちじるしく異なり，それと同 時に摩擦の時間的変動の状態も変わってい ることが注目される。

これらの塞験結果を処理して $\bar{\omega}$ 摩擦卜 ルクの時間平均值: $\vec{f}$ の関係として図示す れば Fig. 6 のようになる.

Fig. 6 飞和いて， $\bar{\omega}$ の小さいところで は $\Gamma$ の值によって $\bar{f}$ の值が異なっている が，これは回転角速度の変動の違いによる ものと考兄られる. この点についてさらに 検討するために，回転角変位 $\theta$ 飞対する $f$ の変化を測定してみると，「の大小にかか わらず同一の結果となり，その一例 (No. 1. モータについては $\bar{\omega}=2 \mathrm{rad} / \mathrm{s}$, No. 2 モ 一タについては $\bar{\omega}=1 \mathrm{rad} / \mathrm{s}$ の場合）を示 せば，Fig. 7 のようになる。

Fig. 7 より，摩擦トルクは $\theta$ とよって変 化していることが明らかである。

の の種々の值に対して， Fig. 7 のよう に $\theta$ 亿対する $f$ の関係を求め, これをモ一 タの 1 回転にわたって平均した值を $\overline{\bar{f}}$ とす る.すなわち、

$$
\overline{\bar{f}}=\frac{1}{2 \pi} \int_{0}^{2 \pi} f d \theta
$$

ただし，亠のの大い場合については， 


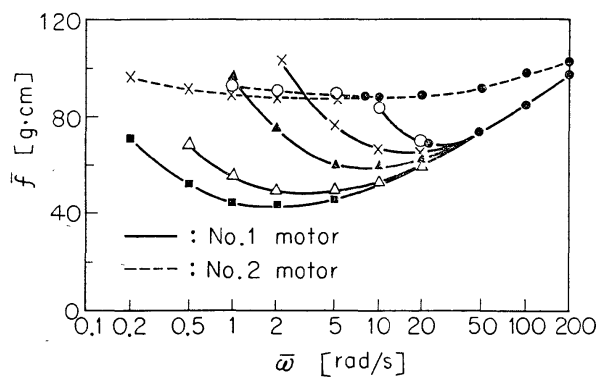

- : $\Gamma=1 \quad \circ: \Gamma=10 \quad \times: \Gamma=50$

А : $\Gamma=100 \quad \triangle: \Gamma=500 \quad$ घ: $: \Gamma=2000$

Fig. 6 Relation between $\bar{\omega}$ and $\vec{f}$ for various values of $\Gamma$

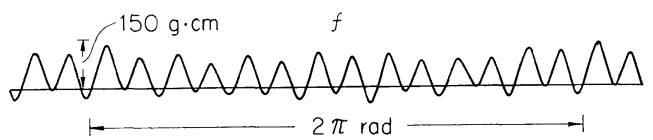

(a)

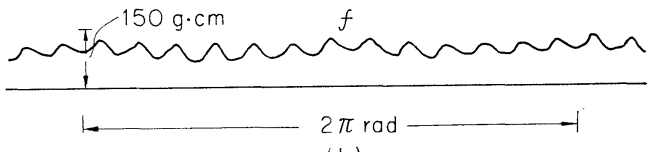

(b)

(a) No.1 motor

(b) No. 2 motor

Fig. 7 Records of $\theta$ vs. $f$ of No. 1 and No. 2 motor

Fig. 7 のような測定結果を得ることは因難なので， この場合は (2) 式を用いて $\overline{\bar{f}}$ を求める.すなわら,

$$
\overline{\bar{f}}=\frac{1}{2 \pi} \int_{0}^{2 \pi} K_{t} i_{a} d \theta-\frac{1}{2 \pi} \int_{0}^{2 \pi} J_{m} \frac{d \omega}{d t} d \theta
$$

$v_{a}$ が一定で，摩擦特性や電機子抵抗の值に時間的 漂動がなく, 外乱もないものとすれば,（6)式の右辺 の第 2 項は零となる. したがって，

$$
\overline{\bar{f}}=\frac{K_{t}}{2 \pi} \int_{0}^{T} i_{a} \omega d t
$$

ここで, $\omega=\frac{d \theta}{d t}, T:$ モータの 1 回転に要する時間

(7) 式は， $\bar{\omega}$ 小さい場合にも適用できるものであ りこれを用いて $\overline{\bar{f}}$ 係なく，（5)式の結果を一致することが確かめられた.

このようにして, 種々の $\bar{\omega}$ に対して求めた $\overline{\bar{f}}$ を図 示すれば Fig. 8 のよらになる.

Fig. 8 の特性は, Fig. 6 に特ける $\Gamma$ の大きい場合 とほとえど同じであることが注目される.

\section{4. 実験結果に対する検討}

（1）モータの摩擦トルクが回転子の角位置によっ て異なるのは，機械的摩擦が位置によって変化するこ とも一因ではあるが，モータによっては，界磁の極数

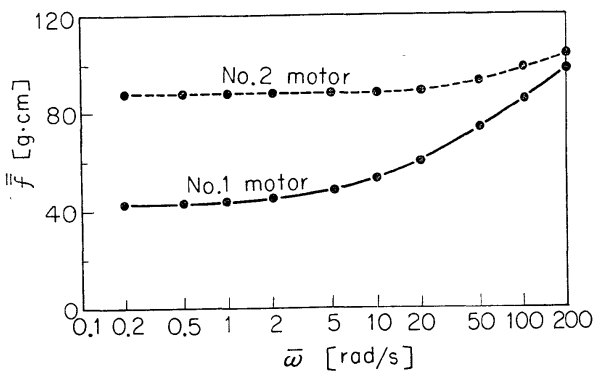

Fig. 8 Relation between $\bar{\omega}$ and $\overline{\bar{f}}$

および電機子のスロット数の相互関係によってその間 の磁気抵抗が最小となるように働くトルクによる影響 が相当に大きく，これが摩擦トルクとして観測される ことによるものと考えられる。

このよらに考えれば，Fig. 3 やFig. 4 で $f$ がわず かではあるが負の側に值を取ることも容易に理解され る.また，No.1 モータでは電機子のスロット数が 7 , 極数が 2 であるが，モータの 1 回転の間に Fig. 7(a) のように $f$ に 14 回の変動を生じて拈り, No. 2 モー タでは極数が 2 , 電機子のスロット数が 13 であるが, この場合は Fig. 7(b) のよらにモータの 1 回転の間 に, $f$ に 13 回の変動を生じているなど, 極数および スロット数に関連した回数の変動を生じていることも これを裏づけている.

な特， $K_{t}$ がモータの回転子の角位置によって変化 しても，上記と同様の結果を生じることが考えられる が, 被測定モ一タに外部から機械的トルクを加え, $K_{t}$ と物理的に等価な逆起電力定数を低回転速度の場合に ついて測定したところ, 角位置によってはほとんど変 化せず，一定值として取り扱ってさしつかえないこと が確かめられている.

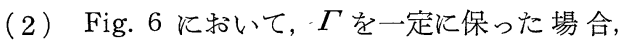
たとえば No. 1 モータでは $0<\bar{\omega}<20 \mathrm{rad} / \mathrm{s}$ の範囲で, ̄の増加に対して $\bar{f}$ の減少するような傾向が見られ る.これは次のよらに考えることができる.

̄が小さい部分では, かららじて回転を持続してい る状態であるため，摩擦が極大となる角位置を通過す る直前では, 回転角速度が極度に減少し, 逆起電力が ほとんど発生しなくなるので，大きな電流が比較的長 時間流れ続ける。しかし，いったん位置の摩擦の極大 值を乗り越えて角位置が進むと, 前とは逆に大きな角 速度で位置の摩擦の次の極大值に近づき, 電流の少な い期間は短時間で終わる. その結果， $\bar{f}$ は大きい值を 取るようになる。

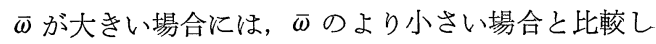
て発生トルクも大きいので, より短い時間で位置の摩 
擦の極大值を乗り越えるようになる。したがって角速 度の低下する（電流の多く流れる）時間は相対的に短 くなりモータが 1 回転する間に流れる電流の平均值も 小さくなって，あたか子摩擦が減少するかのような結 果を呈するものと考光られる．Fig. 4 を及机ば，上 述の考察の妥当であることが理解される.

Fig. 8 の特性は, Fig. 6 そ拈忷る $\Gamma$ の大き場合 の特性と類似の傾向を示している「「が大きいほど, $\omega$ の時間的変動は小さく括さ兄られ， $\omega$ 亿時間的変動 がない場合には $\bar{f}=\overline{\bar{f}}$ となるから, この結果は妥当 なものであることがわかる. Fig. 8 亿示す特性は， 位置によって変化する摩擦の影響を Fig. 6 の特性か ら分離し，摩擦トルクを回転角速度の成分だケによっ て表わしたものとみることができる.

(3) Fig. 7 のような位置によって変化する摩擦 を考えるとき, この摩擦と, 起動をたは停止する前後

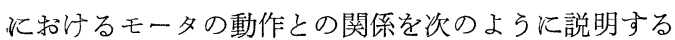

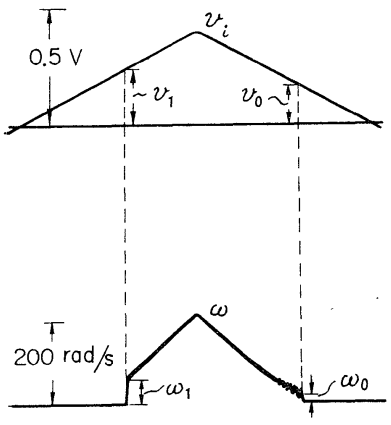

$t^{2 s} \rightarrow$

Fig. 9 Records of $v_{i}$ and $\omega$ of No. 1 motor

\section{ことができる。}

Fig. 9 は, No. 1 モータについて, $v_{i}$ を徐々に上下させた 場合の回転角速度の 変化を記録したもの である。モータが起 動するには，その発 生トルクが, 位置に よって変化する摩擦 トルクの極大值より も大きくなる必要が ある.このときの $v_{i}$ の值を $v_{1}$ とすると， $v_{i}=v_{1}$ に 保持しても，ひとたび位置の摩擦の極大值を乗り越え ると摩擦トルクは逆に減少するので, モータは運動エ ネルギを付与されることになる．この運動エネルギは， 位置の摩擦の次の極大值を乗り越兄るのに利用される ので, 発生トルクの大部分は, モータを平均回転角速 度 $\omega_{1}$ で回転させるために費やされる. 次に回転角速 度を徐々に下げて， $\bar{\omega}=\omega_{0}$ に達すると，このときのモ 一タの発生トルクは小さく, この值に, モータが回転 することによって付与された運動エネルギによるトル クを加えても，その合計が摩擦の極大值を乗り越える のに要する值以下となり，モータは停止することにな る. このときの $v_{i}$ の值を $v_{0}$ とすれば，一般に $v_{0}<v_{1}$, $\omega_{0}<\omega_{1}$ となるのは上述のように説明することができ る.

（4）No.1 モータと No.2 モータの特性は，全体 的にみれば類似の傾向を示しているが，部分的には違
いも認められる. Fig. 6 に打いて, モータ単体では 回転を持続できないような $\bar{\omega}$ 小さいところでは， $\bar{\omega}$ の同じ值に対し，No.1 モータでは $\Gamma$ の大小により $\bar{f}$ の值に大きな差異があり，No. 2 モータではその差異 はわずかである，この違いは，位置によって変化する 摩擦の大小によるものと考学られ, 摩擦の変化分が大 きいほど $\bar{\omega}$ 対 $\bar{f}$ 特性の $\Gamma$ の大小による差異が大きく なる.このことは, Fig. 3 と Fig. 5 あるいは, Fig. 7 の ( a )と (b)を比較してみれば明らかであり, 電機 子のスロット数に相当するものがないために位置によ って変化する摩擦がはるかに小さいプリントモータで 実験を行なってみたところ, 上記の考光の妥当性が裏 づけれた。

\section{5. あとがき}

従来，モータ単体では回転を持続することのできな いような小さな回転角速度に拈ける摩擦特性は測定さ れて和らず，単に推定するにとどまっていた。これを 解決するため, モータに十分な大きさの速度帰還をか け，低速でもモータが回転を持続できるようにし，摩 擦の測定を行なった。

その結果, 回転角速度 $\omega$ の小さいところでは, 従来 から考光られてきたよらにいの関数としてだけではな く, 回転子の角位置にも関係するものと考皇なければ ならないことが明らかとなった。

このような角位置によって変化する摩擦を考慮に入

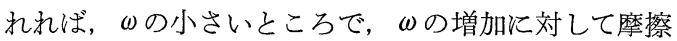
トルクが減少するよらな傾向を示すことや，モータの 起動時と停止時とでは電機子電生が異なった值を取る ことなどを明確に説明することができる。

低速回転時に打ける摩擦特性を知ることは, サーボ モータの製作・試験・選定などや,サーボモータを含 む制御系の計画・解析などに役立つものと考えられる.

また，本論文で提案した測定方法は，これまでほと んど測定することができなかった低速時に特ける一般 的な摩擦の測定にも応用し得るものと考兄られる.

最後に，日ごろから実験に御協力いただいている本 学技官斎藤周次氏ならびに井上文男氏に感謝の意を表 する。

\section{参考 文 献}

1) B. D. Weathers: Analysis and Design of a Servomechanism Using Duration-Quantized Pulse to Drive a D.C. Motor in the Presence of Nonlinear Friction, Ph. D. Thesis, p.17, Kansas State Univ. (1964)

2）鈴木・三浦 : サーボ機構におおる Jerking Motion の 計算, 電学誌, 87-11, 2261/2 268 (昭 42)

3）服部・高梨・安濃 : 直流サーボモータの低速回転に抒 ける摩擦トルクの測定, 計測自動制御学会東北支部第 20 会研究集会資料, $1 / 14$ (昭 43)

4）服部・高梨・安濃：直流サーボモータの回転角度によ る摩擦トルクの变動について, 電気関係学会東北支部 連合大会講演予稿集, p. 121 (昭 43) 